\title{
Peran Bank Syari'ah dalam Pengembangan Dunia Usaha
}

\author{
Muhammad
}

The Shari'ah banking system applies the profit and lose sharing system. This system criticize the weakness of the conventional bank system that covers transaction, bank commitment to save money, the rigidity of transaction, real sector position, and capital return. Departing from those weakness, the shari'ah banking has to play an important role because it rejects interest system or bankung without interest, to bridge economy activities fairly, the shariah banking is free from negarive spread, and it keeps the balancing between real sector and monetery sector.

Kata kunci: bank syariah, pemberdayaan, dan UKM

1 imbul pertanyaan mendasar, mengapa bank syari'ah timbul dan beroperasi? Ada situasi dan keadaan yang menuntut lahir dan beroperasionalnya bank syari'ah. Masalah pokoknya adalah berkenaan dengan perangkat bunga yang telah dikembangkan oleh bank konvensional. Sebab, apabila ditelusuri lebih jauh, bahwa persoalan bunga bank di Indonesia sendiri sudah lama menjadi ganjalan bagi umat Islam yang harus segera ditemukan pemecahannya.

Menurut Muhammad deregulasi finasial yang sedang berlangsung di Indonesia saat ini agaknya sejalan dengan deregulasi finansial yang juga terjadi di negara-negara Asia. Persamaannya terlihat pada tiga dimensi deregulasi yang terpisah, namun berkaitan erat, yaitu : deregulasi harga (terutama deregulasi suku buriga), deregulasi produk (ragam jasa yang ditawarkan), dan deregulasi spasial (kelonggaran pembukaan cabang atau hambatan memasuki pasar). ${ }^{1}$

Lebih lanjut dikatakan, bahwa tinjauan deregulasi selama sepuluh tahun terakhir menunjukkan bahwa deregulasi telah sedikit banyakmengubah "wajah" sektor keuangan Indonesia. Tidak berlebihan bila dikatakan, saat ini Indonesia telah keluar dari represi tinansial, setidaknya kadarnya telah jauh berkurang dibanding masa sebelumnya. Deregulasi finansial sebagai gantinya, mengakibatkan fenomena baru yang mengakibatkan iklim persaingan semakin hangat. ${ }^{2}$ Termasuk di dalamnya adalah persaingan dalam perbankan syari'ah di Indonesia.

'Muhammad, Manajemen Bank Syari'ah, Edisi Pertama, Yogyakarta : UPP AMP-YKPN, 2003, h. 19.

'sbid 
Peran Bank Syari'ah dalam Pèngembangan dan Kemampuannya...; Muhammad

\section{Perkembangan Bank Syariah di Indonesia}

Diakui atau tidak, deregulasi finansial di Indonesia telah memberikan iklim bagi tumbuh dan kembangnya bank syari'ah di - Indonesia. Pada tahun 1991 telah berdiri dua bank syari'ah, yaitu : BPR Syari'ah Dana Mardhotillah; BPR Syari'ah Berkah Amal Sejahtera, keduanya berada di Bandung. Pada tahun 1992, diundangkannya UU Perbankan Nomor 7 tahun 1992, yang isinya tentang bank bagi hasil. Saat itu pula berdiri BankMuamalat Indonesia. Kemudian diikuti oleh BPR Syari'ah Bangun Drajad Warga dan BPR Syari'ah Margi Rizki Bahagia, keduanya berada di Yogyakarta. ${ }^{3}$ Reaksi berikutnya juga muncul, untuk melakukan revisi UU No. 7 tahun 1992 menjadi UU No. 10 Tahun 1998. Dengan demikian, diterbitkannya UU No. 10 tahun 1998 memiliki hikmah tersendiri bagi dunia perbankan nasional di mana pemerintah membuka lebar kegiatan usaha perbankan dengan berdasarkan pada prinsip syariah.

Kalau dilihat secara makro ekonomi, pengembangan bank syariah di Indonesia memiliki peluang besar karena peluang pasarnya yang luas sejurus dengan mayoritas penduduk Indonesia. UU.No.10 tidak menutup kemungkinan bagi pemiliki banknegara, swasta nasional bahkan pihak kesempatan ini jelas akan memperbesar peluang transaksi keuangan di dunia perbankan kita, terutama bila terjalin hubungan kerjasama di antara bank-bank syariah.

Adanya UU No. 10 tahun 1998 ini dapat membawa kesegaran baru bagi dunia perbankan kita. Terutama bagi dunia perbankan syariah di tanah air, berdirinya bank-bank baru yang bekerja berdasarkan prinsip syariah akan menambah semarak lembaga keuangan syariah yang telah ada di sini seperti : Bank Umum Syari'ah, BPR Syari'ah dan Baitul Mal wa Tamwil (BMT).

Memasuki tahun 2005 bank umum yang melakukan kegiatan operasional banksyari'ah meliputi : Bank Muamalah Indonesia, Bank IFI, Bank BNI Syari'ah, Bank Syari'ah Mandiri, BankJabar Syari'ah, BankBukopin, BankBRI Syariah, dan dimungkinkan akan bermunculan konversi bank konvensional ke bank syari'ah (tidakkurang dari54BankKonvensional hingga saat ini sedang antri menunggu ijin untuk pembukaan konversi atau window syariah). Sementara itu, Bank Perkreditan Rakyat Syari'ah (BPRS) di Indonesia telah mencapai sekitar 92 unit BPRS.

Hingga kini, jumlah bank syariah di lndonesia dapat ditunjukkan dalam tabel 1 berikut :

Tabel 1. Perkembangan Kantor Bank Syari’ah (2004-2005)

\begin{tabular}{|l|c|c|c|}
\hline & Des 2004 & Jan 2005 & Sep 2005 \\
\hline Kantor Pusat Bank Umum Syari'ah & 3 & 3 & 3 \\
\hline $\begin{array}{l}\text { Bank Umum Konvensional yang } \\
\text { memiliki Divisi Syari'ah }\end{array}$ & 15 & 15 & 17 \\
\hline Kantor Cabang Syari'ah & 58 & 59 & 86 \\
\hline BPR Syari'ah & 88 & 88 & 92 \\
\hline
\end{tabular}

asing sekalipun untuk membuka cabang syariahnya di Indonesia. Dengan terbukanya
9M. Syafe'i Antonio, Bank Islam : Teori dan Praktek, Jakarta : Gema Insani Press, 2000, hlm. 
Dilihat dari indikator keuangan bank syari'ah menunjukkan perkembangan yang cukup menggembirakan. Aset bank syariah tumbuh dengan cepat termasuk juga penghimpunan dana dan penyaluran pembiayaan. Perhatikan tabel berikut:

\section{Peranan Bank Syariah}

Keberadaan perbankan Islam di tanah air telah mendapatkan pijakan kokoh setelah lahirnya Undang-undang Perbankan Nomor 7 Tahun 1992 yang direvisi melalui Undang

\section{Tabel 2. Perkembangan Pangsa Pasar Bank Syari'ah di Indonesia Agustus 2005 (dalam triliun rupiah)}

\begin{tabular}{|l|c|c|}
\hline \multirow{2}{*}{} & \multicolumn{2}{|c|}{ Bank Syari'ah } \\
\cline { 2 - 3 } & Nominal & Pangsa \\
\hline Total Asset & 18.23 & $1.35 \%$ \\
\hline Dana Masyarakat (DPK) & 13.62 & $1.35 \%$ \\
\hline Pembiayaan & 14.77 & $2.32 \%$ \\
\hline Loand/Financing to Deposit Ratio (FDR) & $108.4 \%$ & \\
\hline Non Performing Loans & $3,8 \%$ & \\
\hline
\end{tabular}

Gambaran di atas menunjukkan, bahwa banksyari'ah perannya dalam perekonomian di Indonesia masih sangat jauh dari harapan jika dibandingkan dengan keseluruhan perbankan di Indonesia. Hal ini disebabkan, karena hingga tahun 2004, jumlah bank syari'ah di Indonesia masih relatif kecil bila dibandingkan dengan jumlah bank konvensional.

Kontribusi bank syari'ah terhadap pertumbuhan ekonomi nasional tersebut sangat ditentukan oleh kemampuan bank syari'ah secara efektif melakukan produksi maupun kemampuan manajerial kelembagaan bank syari'ah tersebut. Kinerja produksi bank syari'ah sangat ditentukan oleh seberapa besar bank syari'ah mampu mengumpulkan dan menyalurkan dana kepada masyarakat, sehingga bank syari'ah mampu menggerakkan roda perekonomian secara optimal.
Undang Nomor 10 tahun 1998, yang dengan tegas mengakui keberadaan dan berfungsinya Bank Bagi Hasil atau Bank Islam. Dengan demikian, bank ini adalah yang beroperasi dengan prinsip bagi hasil. Bagi hasil adalah prinsip muamalah berdasarkan syari'ah dalam melakukan kegiatan usaha bank.

Adanya Bank Syari'ah diharapkan dapat memberikan sumbangan terhadap pertumbuhan ekonomi masyarakat melalui pembiayaan-pembiayaan yang dikeluarkan oleh bank Islam. Melalui pembiayaan ini bank Islam dapat menjadi mitra dengan nasabah, sehingga hubungan bank Islam dengan nasabah tidak lagi sebagai kreditur dan debitur tetapi menjadi hubungan kemitraan.

Secara khusus perarana bank syari'ah secara nyata dapat terwujud dalam aspekaspek berikut : 
1." Menjadi perekat nasionalisme baru, artinya bank syari'ah dapat menjadi :fasilitator aktif bagi terbentuknya jaringan usaha ekonomi kerakyatan. Di samping itu, bank syari'ah perlu mencontoh keberhasilan Sarekat Dagang. Islam, kemudian ditarik keberhasilannya untuk masa kini (nasionalis, demokratis, religius, ekonomis)

2. Memberdayakan ekonomi umat dan beroperasi secara transparan. Artinya, pengelolaan bank syari'àh harus didasarkan pada visi ekonomi kerakyatan, dan upaya ini terwujud jika ada mekanisme operasi yang transparan.

3. Memberikan return yang lebih baik. Artinya investasi di bank syari'ah tidak memberikan janji yang pasti mengenai return (keuntungan) yang diberikan kepada investor. Oleh karena itu, bank syari'ah harus mampu memberikan return yang lebih baik dibandingkan dengan bank konvensional. Di samping itu, nasabah pembiayaan akan memberikan bagi hasil sesuai dengan keuntungan yang diperolehnya. Oleh karena itu, pengusaha harus bersedia memberikan keuntungan yang tinggi kepada bank syari'ah

4. Mendorong penurunan spekulasi di pasar keuangan. Artinya, bank syari'ah mendorong terjadinya transaksi produktif dari dana masyarakat. Dengan demikian, spekulasi dapat ditekan.

5. Mendorong pemerataan pendapatan. Artinya, bank syari'ah bukan hanya mengumpulkan dana pihak ketiga, namun dapat mengumpulkan dana Zakat, Infaq dan Shadaqah (ZIS). Dana ZIS dapat disalurkan melalui pembiayaan Qardul Hasan, sehingga dapat mendorong pertumbuhan ekonomi.Pada akhirnya terjadi pemerataan ekonomi.

6. Peningkatan efisiensi mobilisasi dana. Artinya, adanya produk al-mudharabah al-muqayyadah, berarti terjadi kebebasan bank untuk melakukan investasi atas dana yang diserahkan oleh investor, maka bank syari'ah sebagai financial arranger, bank memperoleh komisi atau bagi hasil, bukan karena spread bunga.

7. Uswah hasanah implementasi moral dalam penyelenggaraan usaha bank.

8. Salah satu sebab terjadinya krisis adalah adanya Korupsi, Kolusi dan

9. Nepotisme (KKN).

Bank syari'ah karena sifatnya sebagai bank berdasarkan prinsip syari'ah wajib memposisikan diri sebagai uswatun hasanah dalam implementasi moral dan etika bisnis yang benar atau melaksanakan etika dan moral agama dalam aktivitas ekonomi.

\section{Tantangan Bank Syariah (BPR Syariah) atas Perubahan Dunia Usaha}

Bank syari'ah adalah bank yang aktivitasnya meninggalkan masalah riba. Dengan demikian, penghindaran bunga yang dianggap riba merupakan salah satu tantangan yang dihadapi dunia Islam dewasa ini. Suatu hal yang sangat menggembirakan bahwa belakangan ini para ekonom Muslim telah mencurahkan perhatian besar, guna menemukan cara untuk menggantikan sistem bunga dalam transaksi perbankan dan keuangan yang lebih sesuai dengan etika Islam. Upaya ini dilakukan dalam upaya untuk membangun model teori ekonomi yang bebas bunga dan pengujiannya terhadap pertumbuhan ekonomi, alokasidan distribusi pendapatan. 
Oleh karena itulah, maka mekanisme perbankan bebas bunga - yang biasa disebut dengan bank syari'ah - didirikan. Perbankan syari'ah didirikan didasarkan pada alasan filosofis maupun praktik. Secara filosofis, karena dilarangnya pengambilan riba dalam transaksi keuangan maupun non keuangan. ${ }^{4}$ Secara praktis, karena sistem perbankan berbasis bunga atau konvensional mengandung beberapa kelemahan, sebagai berikut:

1. Transaksi berbasis bunga melanggar keadilan atau kewajaran bisnis.

2. Tidak fleksibelnya sistem transaksi berbasis bunga menyebabkan kebangkrutan.

3. Komitmen bank untuk menjaga keamanan uang deposan berikut bunganya membuat bank cemas untuk mengembalikan pokok dan bunganya.

4. Sistem transaksi berbasis bunga menghalangi munculnya inovasi oleh usaha kecil.

5. Dalam sistem bunga, bank tidak akan tertarik dalam kemitraan usaha kecuali bila adajaminan kepastian pengem-balian modal dan pendapatan bunga mereka. ${ }^{5}$

Berangkat dari beberapa kelemahan sistem perbankan konvensional tersebut, maka perbankan syari'ah diharapkan mendapatkan kebebasan dalam mengembangkan produknya sendiri, sesuai dengan teori perbankan syari'ah. Jika kebebasan ini dapat diwujudkan maka secara ideal akan memberikan manfaat bagi : (a) terpeliharanya aspek keadilan bagi para pihak yang bertransaksi; (b) lebih menguntungkan dibanding perbankan konvensional; (c) dapat memelihara kestabilan nilai tukar mata uang karena selalu terkait dengan transaksi riil, bukan sebaliknya; (d) transparansi menjadi sifat yang melekat (inheren); dan (e) memperluas aplikasi syari'ah dalam kehidupan masyarakat Mustim. ${ }^{6}$.
Oleh karena itu, bank syari'ah perlu mengembangkan skim pembiayaan yang tepat untuk dapat mendorong tumbuh dan perkembangan dunia usaha. Selama ini, dunia usaha selalu mengelami perkembangan yang sangat cepat. Sementara, terkadang untuk pengembangannya kurang didukung oleh dana yang mencukupi. Kalaupun ada, tingkat suku bunga yang disyaratkan cukup tinggi. Hal demikian ini dapat mengganggu perkembangan dunia usaha. Oleh karena itu, peran bank syari'ah sangat diperlukan untuk menunjang pertumbuhan dunia usaha, utamanya usaha kecil dan menengah (UKM). Sebab, kelompok dunia usaha inilah yang selalu berhadapan dengan persoalan kekurangan dana.

\section{Potensi Bank Syariah dalam Pengembangan UKM}

Bank syari'ah merupakan lembaga perantara keuangan dari masyarakat yang surplus dana kepada masyarakat minus dana. Dilihat dari jumlah unit úsaha, di Indonesia masih didominasi oleh usaha kecil dan menengah (UKM). Dengan demikian, masalah UKM periu memperoleh perhatian serius dari pemerintah. Sebab keberadaannya dapat menggerakkan perekonomian Indonesia. Akan tetapi, UKM biasanya kesulitan berkembang karena kurangnya modal. Oleh karena itu, jika ingin mengembangkan UKM, maka porsi sumber dana dari pemerintah perlu penyeluran secara baik, melalui bank-bank yang dapat

${ }^{4}$... Allah menghalalkan jual-beli dan mengharamkan riba ... (QS. Al-Baqarah (2) : 275)

5Zaenul Arifin, Dasar-dasar Manajemen Bank Syariah, Jakarta: Affabeta, 2002, h. 39-40. s/bid 
akses langsung ke masyarakat kecil. Termasuk di dalamnya adalah BPR Syari'ah.

Masalah pendanaan kepada UKM sebenarnya telah diperhatikan oleh Pemerintah, melalui Keputusan Menteri Keuangan Nomor 40/KMK.06/2003 tentang Pendanaan Kredit Usaha Mikro dan kecil tanggal 29 Januari 2003, Pèmerintah telah menyediakan fasilitas pinjaman untuk usaha mikto dan kecil yang dananya berasal dari Surat Utang pemerintah (SUP). Sesuai dengan Pasal 5 Keputusan Menteri Keuangan Nomor 4-/KMK.06/2003 tersebut, Kredit Usaha Mikro dan Kecil (KUMK) disalurkan dengan dua pola, sebagai berikut:

a. Dana SUP dipinjamkan Pemerintah kepada BUMN Pengelola, dan selanjutnya oleh BUMN Pengelola dipinjamkan kembali kepada Lembaga Keuangan Pelaksana (LKP) yang ditunjuk oleh BUMN Pengelola dalam rangka pendanaan KUMK kepada usaha mikro dan kecil,

b. Dana SUP dipinjamkan oleh Pemerintah langsung kepada LKP yang ditunjuk oleh Menteri Keuangan dalam rangka pendanaan KUMK kepada usaha mikro dan kecil.

Meskipun demikian ada perbedaan antara bank syari'ah dengan bank konvensional, utamanya dalam menangani persoalan pembiayaan bagi dunia usaha UKM. Skim pembiayaan dalam bank syari'ah memiliki karakteristik yang khusus, jika dibandingkan dengan bank konvensional. Penilaian kelayakan pada pembiayaan pada bank konvensional lebih ditekankan pada aspek bisnis semata, sedangkan pada bank syari'ah selain didasarkan pada aspek bisnis juga harus mempertimbangkan aspek syari'ah. Secara umum skim pembiayaan di bank syari'ah, meliputi: skim jual beli (murabahah, salam, dan istishna), skim sewa (jarah, ijarah wa iqtina), skim bagi hasil (mudharabahatau musyarakah), dan skim pinjaman (qard).

Dalam kaitannya dengan keterbatasan UKM, ada tiga alternatif pembiayaan yang dapat dilakukan oleh bank syari'ah, yaitu: skim jual beli, skim bagi hasil dan skim pinjaman. Qardh adalah suatu pinjaman yang dikembalikan pada akhir periode yang telah disepakati tanpa disertai bunga atau keuntungan atau kerugian bisnis. Pembiayaan ini dikhususkan untuk para pelaku UKM yang baru merintis bisnis (inkubator-inkubator wirausahawan).

Sementara, bagi UKM yang sudah berkembang, yang membutuhkan dana untuk investasi, maka bank syari'ah menyediakan skim pembiayaan dengan konsep jual beli. Skim lain yang dapat digunakan oleh bank syari'ah dalam kaitannya dengan pembiayaan kepada UKM adalah skim mudharabah. Mudharabah adalah suatu bentuk kemitraan di mana salah satu mitra, shohibul-maal (penyedia dana), menyediakan sejumlah modal tertentu dan bertindak sebagai mitra pasif (mitra tidur), sedangkan yang lain disebut mudharibyang menyediakan keahlian usaha dan manajemen untuk menjalankan usaha dengan tujuan mendapatkan laba. Jadi, pembiayaan mudharabah adalah pembiayaan antar pemilik dana (bank) dengan pihak yang memiliki keahlian untuk mengelola usaha produktif dan halal, dimana pembagian keuntungan dari usaha dilakukan sesuai nisbah yang disepakati bersama.

Dengan demikian dapat dikatakan, bahwa sistem perbankan syari'ah - yang beroperasi dengan berbagai risiko dan hasil - memiliki beberapa keunggulan, antara lain: (1) bank tidak mambatasi dirinya hanya bersedia meminjamkan dananya kepada sektor usaha yang sudah berjalan dan mapan atau kepada orang yang dapat menyediakan agunan guna memastika 
pembayaran kembali hutang pokok dan bunganya, sebagaimana berlaku pada sistem perbankan konvensional; (2) bank bekerja berdasarkan prinsip kemitraan dengan para pengusaha. Pembiayaan yang diberikan oleh bank diserta dengan pembelian konsultasi, pembinaan dan pengawasan, bahkan jika perlu menempatkan orang untuk membantu secara aktif dalam proses manajemen usaha.

Oieh karena itu, potensi bank syari'ah (termasuk BPR Syari'ah) dalam pengembangan UKM, akan sangat tergantung pada faktor-faktor berikut:

1. Perkembangan dana-dana qardul hasan serta dana-dana investasi mudharabah dengan jangka waktu yang sesuai siklus usaha yang dibiayai bank.

2. Perkembangan jumlah pemilik dana yang lebih suka menanamkan dananya dalam bentuk investasi daripada menyimpannya dalam bentuk simpanan berpendapatan pasti

3. Perkembangan kualitas sumber daya insani, baik bank syari'ah maupun UKM

4. Perkembangan jumlah pengusaha yang bersedia ber-bank syari'ah

5. Perkembangan infrastruktur, termasuk perbankan yang lebih sesuai dengan karakteristik sistem perbankan syari'ah.

\section{Harapan Pengusaha pada Bank Syariah}

Hadirnya Bank Syariah di Indonesia telah mencapai 16 tahun yang lalu telah memberi warna baru dalam perekonomian Indonesia. Sebuah lembaga keuangan dengan konsep syariah mencoba hadir mengisi kekosongan yang terjadi selama ini. Bagi umat Islam, termasuk para pengusahanya - yang ingin menjalankan kehi- dupan keislaman secara kaffah (total), kehadiran lembaga keuangan dengan dasar syariah ini tentu saja sangat membahagiakan.

Kalau ukuran memilih lembaga keuangan syariah semata-mata dengan landasan iman, persoalannya memang menjadi sederhana. Tidak perduli apakah lembaga keuangan itu lebih menguntungkan apa tidak bila dibanding lembaga kèuangan konvensional, seorang yang beriman tentu tetap memilih lembaga keuangan syariah atas dasar keimanannya. Namun ini tentu tidak realistis dalam kehidupan sehari-hari. Seorang pelaku bisnis - meski ia seorang muslim taat sekalipun - tentu akan melakukan kalkulasi yang teliti sebelum memutuskan ia akan memanfaatkan lembaga keuangan syariah. Idealnya, paduan antara keimanan seorang pelaku bisnis dengan perhitungan bisnis yang wajar, akan membawa yang bersangkutan pada satu pilihan sadar bahwa berbisnis dengan lembaga keuangan syariah, InsyaAllah akan membawa keuntungan dunia dan akhirat sekaligus.

Salah satu produk perbankan syariah yang banyak dimanfaatkan oleh pengusaha adalah skim murabahah. Biasanya pengusaha menggunakan skim ini untuk memenuhi kebutuhan modal kerjanya. Akad murabahah adalah akad jual beli, yang dalam kaitan produk perbankan syariah menempatkan bank sebagai pedagang. Dalam transaksi ini, bila seseorang pengusaha membutuhkan barang modal, misalnya forklift, maka ia minta kepada bank untuk membelikan forklift terlebih dahulu dengan harga Rp 150 jutamisalnya. Bank kemudian menetapkan margin sebesar Rp 20 juta dan disetujui oleh nasabah yang membutuhkan barang tersebut: Dengan demikian harga forklift menjadi Rp 190 juta dan disepakati akan diangsur selama tiga tahun secara flat. 
Perhitungan di atas sekadar contoh untuk memberikan gambaran.

Dalam transaksi konvensional, pengusaha biasanya menggunakan leasing untuk memperoleh barang modal. Pengertian leasing adalah: setiap kegiatan pembiayaan perusahaan dalam bentuk menyediakan barang-barang modal untuk digunakan oleh suatu perusahiaan dalam jangka waktu tertentu. Pengusaha melakukan pembayaran-pembayaran berkala disertai dengan hak pilih bagi penusahaan tersebut untukmembeli barangbarang modal yang besangkutan atau memperpanjang jangka waktu leasing berdasarkan nilai sisa yang telah disepakati bersama.

Persoalannya adalah, dunia usaha masih memiliki kesan kuat bahwa pembiayaan murabahah lebih mahal dibandingkan dengan leasing untuk barang dan periode angsuran yang sama. Kesan ini akan membuat pengusaha surut langkahnya menuju ke banksyariah, terlebih bila pengusaha tadi hanya semata-mata mengandalkan hitungan bisnis semata. Karena itu, masalah ini harus segera dibuktikan secara ilmiah benar atau tidak. Bila benar harus segera dicari jalan untuk mengatasinya, bila tidak benar harus pula segera disosialisasikan ketidakbenaran itu pada masyarakat. Saya sendiri sebagai pengusaha juga merasakan hal itu untuk beberapa produk yang saya peroleh dari pembiayaan bank syariah. Hanya saja saya masih bisa memahami, karena skala ekonomi nasabah bank syariah memang belum tercapai. Jika nasabahnya semakin banyak, insyaAllah pembiayaan bank syariah akan kompetitif.

Sebenarnya bank bisa mendapatkan harga kompetitif dari produsen, bila ia mau sedikit susah payah melakukan negoșiasi dengan produsen. Dengan mengandalkan kemungkinan untuk melakukan pembelian dalam jumlah banyak atau pembelian berulang, bank sebenarnya memiliki posisi tawar cukup tinggi. Persoalannya, bank akhirnya mewakilkan kepada nasabah (wakalah) untuk membeli barang yang dibutuhkannya. Tentu saja seorang nasabah individu tidak punya posisi tawar memadai di hadapan produsen.

-Persoalan lain yang juga membuat pengusaha enggan ke bank syariah adalah lamanya proses persetujuan pembiayaan. Di perusahaan leasing, proses persetujuan pembiayaan bisa hanya berlangsung selama tiga hari sampai satu minggu. Sedangkan di bank syariah, karena prosesnya yang lebih panjang - termasuk memerlukan persetujuan direksi - persetujuan pembiayaan bisa butuh waktu sampai satu bulan bahkan lebih. Tentu saja sebuah peluang bisa hilang karena lamanya proses persetujuan ini.

Tak kalah pentingnya peran Dewan Pengawas Syariah (DPS) harus benar-benar kuat dalam menjaga bank syariah tetap di rel syariah. Bila tidak, pengusaha muslim yang paham ekonomi Islam akan meninggalkannya, dan bank syariah justru akan dimanfaatkan oleh pihak lain yang tidak peduli soal ketaatan syariah.

Perbankan syariah tengah berproses menuju kesempurnaan. "Hari ini lebih baik dari kemarin" tentu harus menjadi pegangan dasar bagi mereka yang kebetulan mendapat amanah untuk mengelola perbankan syariah. Sebagai pengusaha muslim, berharap proses itu tidak terlalu lama, sehingga segera bisa berbisnis dengan dukungan pembiayaan yang halal dan thayib. 
Topik: Keterpaduan Sektor Formal dan Informal Perkotaan

\section{Penutup}

Sebagai penutup dari makalah ini dapat cisampaikan bahwa sistem perbankan syariah merupakan sistem yang paling tepat untuk menumbuh-kembangkan bidang usaha, baik yang akan berdiri atau yang telah berdiri. Sebab sistem perbankan syari'ah memberikan variasi skim pembiayaan yang paling tepat bagi para pengusaha, utamanya usaha kecil dan menengah.

Pemberdayaan UKM bukan saja menjadi tanggung jawab salah satu pihak saja, melainkan menjadi tanggung jawab semua pihak, pemerintah, BUMN, BUMS, dan segenap lapisan masyarakat. Upaya untuk mencari jalan keluar dari kendalakendala yang dihadapi oleh UKM telah banyak dilakukan, namun upaya tersebut hendaknya dilakukan secara berkelanjutan dan komitmen yang tinggi. Di sinilah peran BPR Syari'ah dalam menyelesaikan kendala yang dihadapi oleh UKM untuk mengakses pasar dan informasi.

\section{Daftar Pustaka}

Muhammad, 2003, Manajemen Bank Syari'ah, Edisi Pertama, Yogyakarta : UPP AMP-YKPN,

M. Syafe'i Antonio, 2000, Bank Islam: Teori dan Praktek, Jakarta : Gema Insani Press,

Zaenul Arifin, 2002, Dasar-dasarManajemen Bank Syari'ah, Jakarta : Alfabeta. 